Journal of Law, Administration, and Social Science

Volume 2 No. 1, 2022

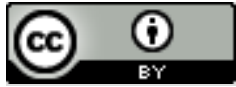

\title{
URGENSI KUHD DALAM MENANGANI RISIKO KEJAHATAN SIBER PADA TRANSAKSI E-COMMERCE
}

\author{
(Pentingnya Kodifikasi Ketentuan Umum Hukum Dagang sebagai respon pemerintah terhadap \\ perlindungan konsumen dalam transaksi e-commerce)
}

\author{
Eka Nadia Septiani Ady ${ }^{1)}$; Faiza Batrisya Nisrina ${ }^{2)}$; Fidyah Ramadhani ${ }^{3)}$; Ferry Irawan ${ }^{4 *}$ \\ 1)4131210062_eka@pknstan.ac.id,Politeknik Keuangan Negara STAN \\ 2)4121210026_faiza@pknstan.ac.id, Politeknik Keuangan Negara STAN \\ 3) 4131210024_fidyah@pknstan.ac.id, Politeknik Keuangan Negara STAN \\ 4)ferry.irawan@pknstan.ac.id, Politeknik Keuangan Negara STAN* \\ *penulis korespondensi
}

\begin{abstract}
In this increasingly dynamic era of globalization, the conventional buying and selling system is slowly fading away because it does not accommodate the wishes of consumers who want to conduct transactions efficiently and flexibly using only computers or mobile phones and connected to the internet by opening online shopping sites. Thus, it can be concluded that the existence of e-commerce is the best and efficient solution for the community. However, in the current e-commerce era, many online transactions are at risk, one of which is the leakage of user data. When we surf the world of the internet we are very close to the possibility of data leakage. This study aims to determine the urgency of the general provisions of commercial law in dealing with cybercrime risks in the e-commerce era. The qualitative method with a juridical normative approach is the analytical method used in this study. The results of the study indicate that the General Provisions of Commercial Law require legal codification to adjust the provisions in accordance with the development and needs of the community. Suggestions in this study are that it is necessary to immediately complete the draft of the codification of the KUHD in order to create certainty and protection for consumer personal data.

Keywords : Commercial Code, Consumer Protection, Data Leakage, E-commerce, Cybercrime
\end{abstract}

\begin{abstract}
Abstrak
Di era globalisasi yang kian dinamis kini, sistem jual beli konvensional perlahan memudar karena tidak mengakomodasi keinginan para konsumen yang ingin melakukan transaksi dengan efisien dan fleksibel hanya dengan menggunakan sarana komputer atau handphone dan terhubung jaringan internet dengan membuka situs-situs belanja online. Sehingga, dapat disimpulkan bahwa eksistensi perdagangan elektronik (e-commerce) menjadi solusi terbaik dan efisien bagi masyarakat. Namun, dalam era perdagangan elektronik kini banyak transaksi daring yang beresiko salah satunya adalah kebocoran data pengguna. Saat kita berselancar dengan dunia internet kita sangat dekat dengan adanya kemungkinan kebocoran data. Penelitian ini bertujuan untuk mengetahui urgensi ketentuan umum hukum dagang dalam menangani risiko cybercrime di era e-commerce. Metode kualitatif dengan pendekatan normatif yuridis adalah metode analisis yang digunakan dalam penelitian ini. Hasil dari penelitian menunjukkan bahwa Ketentuan Umum Hukum Dagang memerlukan kodifikasi hukum untuk menyesuaikan ketentuannya sudah sesuai dengan perkembangan dan kebutuhan masyarakat. Saran dalam penelitian ini adalah diperlukan segera penyelesaian rancangan kodifikasi KUHD agar terciptanya kepastian dan perlindungan bagi data pribadi konsumen.
\end{abstract}

Kata Kunci : KUHD, Perlindungan Konsumen, Kebocoran Data, Perdagangan Elektronik, Kejahatan Siber

\section{PENDAHULUAN}

Perkembangan teknologi dan informasi telah menyebabkan reformasi kemajuan dalam sistem perdagangan di Indonesia dari tahun ke tahun. Hal ini dibuktikan dengan adanya perdagangan elektronik yang memudahkan proses jual-beli suatu barang, jasa, sandang, pangan, dan lain sebagainya menjadi lebih praktis, ekonomis dan cepat. Perkembangan dalam sistem perdagangan inilah yang menjadi cikal bakal tumbuhnya electronic commerce yang disebut sebagai e-commerce. E-commerce aktivitas komersial online yang berperan dalam pertukaran dan transaksi jual-beli barang/jasa yang difasilitasi dengan sarana elektronik, salah satunya adalah internet. Dengan adanya $e$-commerce yang memudahkan transaksi jual-beli tidak mengharuskan konsumen 


\section{Journal of Law, Administration, and Social Science}

dan pengguna bertemu secara langsung (face to face). Pembayaran juga dilakukan secara online seperti menggunakan mobile banking, shopee pay, dan transaksi online lainnya. Hal tersebut tentu sangat memudahkan penjual dan konsumen bertransaksi tanpa ada batasan waktu dan tempat. Oleh karena itu, e-commerce merupakan perantara antara konsumen dan penjual yang sangat efektif dan terbaik di era globalisasi ini (Ramli et al., 2020).

Kehadiran e-commerce dalam sistem perdagangan menyebabkan semakin beragamnya kebutuhan masyarakat karena dapat memilih dan melihat barang yang dijual melalui situs-situs online dengan lebih mudah. Sebuah badan usaha milik Singapura yaitu TEMASEK dan Google telah merilis The Opportunity of Indonesia (2017) yang menunjukkan kenaikan pertumbuhan $e$ commerce pada masyarakat Indonesia seiring melonjaknya penggunaan internet di Indonesia. Peningkatan ini mengerek naik nilai pasar e-commerce Indonesia. Selain itu, TEMASEK dan Google memprediksi bahwa nilai pasar e-commerce Indonesia akan mencapai angka \$81 miliar pada tahun 2025 (Harahap, 2018).

Peningkatan signifikan dalam arus jual-beli tentunya perlu diwaspadai, karena transaksi $e$ commerce memiliki risiko yang lebih besar dibandingkan transaksi perdagangan konvensional (Murifal, 2018). Namun, selain memberikan keuntungan penggunaan e-commerce juga dapat menimbulkan kerugian bagi para penggunannya. Salah satu kerugian yang sangat berakibat fatal adalah serangan cybercrime yang dapat menimbulkan kebocoran data pengguna bahkan penyalahgunaan data untuk tindakan kriminal. Kasus kejahatan cybercrime dalam transaksi $e$ commerce paling terbaru yaitu kebocoran data pribadi marketplace Tokopedia yang terjadi di awal Mei 2020. Diketahui bahwa sekitar 91 juta data akun pengguna Tokopedia diretas dan dijual di darkweb dengan harga US\$ 5000. Kasus tersebut dimulai pada 20 Maret 2020, tindakan peretasan yang dilakukan Whysodank. Pada Sabtu, 2 Mei 2020, akun Whyosodank membocorkan hasil peretasan di Raid Forum. Selanjutnya, pada hari yang sama akun @underthebreach yang mengklaim sebagai layanan pengawasan dan pencegahan kebocoran data asal Isreal membuat ciutan tentang peretasan akun Tokopedia di Twitter. Dalam ciutan tersebut akun @ underthebreach mengatakan bahwa ada sekitar data pribadi 15 juta akun yang diretas. Data pribadi tersebut terdiri dari user ID, email, nama lengkap, tanggal lahir, jenis kelamin, nomor handphone dan password yang masih ter-hash atau tersandi.17 Pada hari Minggu 3 Mei 2020, Whysodank telah mengumuman telah menjual seluruh 91 juta data pengguna Tokopedia di forum darkweb bernama EmpireMarket (Fathur, 2020; Komalawati et al., 2021; Utami et al., 2022).

Hal tersebut tentunya menjadi permasalahan yang dapat membahayakan para pengguna $e$ commerce dan menjadi ancaman serius. Penyebab utama dari serangan cybercrime yang timbul akibat transaksi online e-commerce adalah jaringan internet yang memfasilitasi penggunaan $e$ commerce (Sumadi, 2016). Jaringan internet merupakan jaringan terbuka dan bebas diakses kapanpun, siapapun, dan dimanapun. Sehingga, mudah sekali bagi para peretas untuk melakukan kejahatan cybercrime untuk melakukan aksi kejahatan dalam transaksi e-commerce (Sewang, 2017).

Adanya serangan kejahatan siber sebagai risiko transaksi $e$-commerce mengharuskan para penyedia layanan e-commerce mencari solusi untuk melindungi keamanan konsumen seperti seperti digital signature, kunci kriptografi, dan Secure Electronic Transaction (SET) yang memiliki tujuan sebagai perlindungan dari serangan cybercrime bagi konsumen (Frastian, 2017; Bunga, 2019). Namun, perlu diingat bahwa solusi tersebut tidak dapat mengatasi serangan cybercrime dalam sekala makro. Sehingga, diperlukan suatu undang-undang yang mengatur mengenai perlindungan konsumen dalam transaksi e-commerce untuk menghindari risiko yang dapat mengancam keamanan konsumen (Makarim, 2014; Rongiyati, 2019). 


\section{Journal of Law, Administration, and Social Science}

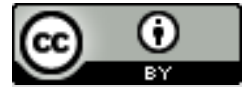

Di Indonesia terdapat aturan yang mengatur tentang perdagangan yang dimuat dalam Ketentuan Umum Hukum Dagang (Dani \& Marlinah, 2019). Salah satu pasal dalam Ketentuan Umum Hukum Dagang yaitu Pasal 246 Bab IX Tentang Asuransi Atau Pertanggungan Pada Umumnya, asuransi atau pertanggungan adalah perjanjian, di mana penanggung mengikat diri terhadap tertanggung dengan memperoleh premi, untuk memberikan kepadanya ganti rugi karena suatu kehilangan, kerusakan, atau tidak mendapat keuntungan yang diharapkan, yang mungkin akan dapat diderita karena suatu peristiwa yang tidak pasti. Pasal tersebut sudah menyinggung mengenai perlindungan dan biaya kompensasi yang diberikan kepada pihak pembeli dan pihak penjual apabila mendapatkan kerugian atau keuntungan yang tidak diharapkan salah satunya adalah serangan cybercrime yang dapat terjadi saat transaksi e-commerce (Pariadi, 2018). Akan tetapi, pasal tersebut tidak cukup untuk mengatur ketentuan perlindungan hukum bagi penjual dan pembeli dalam transaksi e-commerce (Sadino \& Dewi, 2016; Subekti, 2017) .

Oleh karena itu, peran pemerintah sangat diperlukan sebagai payung hukum bagi pihak penyedia layanan e-commerce, penjual, maupun pihak pembeli dalam transaksi electronic commerce untuk mengatasi adanya kerugian dalam transaksi e-commerce melalui peraturan pemerintah (Irmawati, 2011; Lukito, 2017). Namun, sistem perdagangan yang diatur dalam KUHD tidak menjelaskan bagaimana perlindungan terhadap konsumen yang rentan terhadap risiko cybercrime dalam transaksi e-commerce. Ketiadaan undang-undang khusus terkait perlindungan data pribadi menyulitkan konsumen apabila terjadi pelanggaran atas data pribadi konsumen itu sendiri, artinya tidak ada landasan hukum yang khusus yang dapat digunakan oleh konsumen dalam memperjuangkan haknya .

Tujuan penelitian ini untuk menelaah (1) bagaimana tinjauan yuridis perlindungan hukum bagi konsumen dalam transaksi e-commerce?; (2) bagaimana urgensi KUHD dalam mengatasi risiko cybercrime yang muncul dalam transaksi e-commerce?; dan (3) bagaimana penyelesaian sengketa antara konsumen dengan pelaku usaha dalam transaksi dagang melalui transaksi $e$ commerce?.

\section{KAJIAN PUSTAKA}

Perkembangan e-commerce dalam sistem perdagangan menimbulkan risiko yang tinggi pula atas kejahatan dalam transaksi e-commerce (Fitriono, 2011). Untuk dapat melindungi konsumen e-commerce, maka hak-hak konsumen e-commerce harus dipenuhi, baik oleh negara maupun pelaku usaha, karena pemenuhan hak-hak konsumen tersebut akan melindungi kerugian konsumen dari berbagai aspek dan melekat pada setiap konsumen. Dalam hal ini negara memiliki kewajiban untuk melindungi konsumen e-commerce baik secara preventif maupun represif melalui regulasi dan kebijakan yang dikeluarkan oleh negara. Perlindungan hukum diperlukan sebagai tindakan atau upaya untuk melindungi masyarakat dari perbuatan sewenang-wenang oleh penguasa yang tidak sesuai dengan aturan hukum, dalam rangka mewujudkan ketertiban dan ketentraman sehingga memungkinkan manusia untuk menikmati martabatnya sebagai manusia (Eshafia, 2022). Di samping itu, perlindungan hukum juga diperlukan sebagai upaya untuk melindungi individu dengan menyerasikan hubungan nilai-nilai atau kaidah-kaidah yang menjelma dalam sikap dan tindakan dalam menciptakan adanya ketertiban dalam pergaulan hidup antar sesama manusia.

Perkembangan e-commerce mengakibatkan kenaikan perekonomian negara secara signifikan. Sebagai bentuk timbal balik, sudah seharusnya pemerintah dapat melindungi konsumen dan pelaku usaha karena pemenuhan hak-hak konsumen tersebut akan melindungi kerugian konsumen dari berbagai aspek dan melekat pada setiap konsumen. Negara tentunya dapat melindungi konsumen secara preventif maupun represif melalui peraturan pemerintah yang 


\section{Journal of Law, Administration, and Social Science}

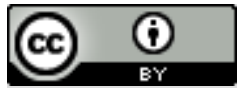

dirancang khusus untuk perlindungan konsumen. Salah satunya adalah melalui Kitab UndangUndang Hukum Dagang (KUHD) (Kathleen et al., 2021).

Hukum Dagang adalah bagian khusus dari Hukum Perdata, yang mengatur hubungan hukum individu satu dengan individu yang lain di dalam suatu perjanjian khusus berdasarkan kehendak bebas. Sejalan dengan dinamika dan kompleksitas bisnis dan perdagangan, pengaturan hukum dagang yang terpisah dari Hukum tetap diperlukan agar mampu mengakomodasi perkembangan praktik bisnis dan perdagangan (Budianto, 2013).

Bukti adanya hubungan antara Kitab Undang-Undang Hukum Dagang dengan Kitab Undang-Undang Hukum Perdata, tertuang pada pasal 1 KUHD (Kitab Undang-Undang Hukum Dagang) yang menyebutkan bahwa: "Kitab Undang-Undang Hukum Perdata, seberapa jauh dalam Kitab Undang-Undang Hukum Dagang ini tidak khusus diadakan penyimpangan-penyimpangan, berlaku juga terhadap hal-hal yang disinggung dalam kitab ini."

Mengenai hubungan tersebut berlaku adagium "Lex Specialis Derogat Legi Generale" yang berarti hukum khusus mengalahkan hukum umum atau dengan kata lain hukum khusus mengesampingkan hukum umum. Artinya bahwa apabila suatu ketentuan telah diatur dalam Kitab Undang-Undang Hukum Dagang, maka ketentuan yang mengatur hal yang sama dalam Kitab Undang-Undang Hukum Perdata menjadi tidak berlaku.

Hukum dagang menjadi sarana pembatas dalam kegiatan perdagangan. Hukum dagang hadir untuk menjawab praktik perdagangan yang semakin variatif di lingkungan masyarakat. Kebutuhan masyarakat yang berkembang dan cara transaksi yang beragam tentunya menimbulkan berbagai permasalahan yang beragam juga. Namun, pada nyatanya hukum dagang tidak sesuai dengan perkembangan terkini dan belum mampu mengatur permasalahan sistem perdagangan terkini.

\section{METODE}

Penelitian menggunakan pendekatan yuridis-normatif, yaitu jenis pendekatan dengan menggunakan ketentuan perundang-undangan yang berlaku pada suatu negara atau metode pendekatan hukum doktrinal yaitu teori-teori hukum dan pendapat para ilmuwan hukum terutama yang berkaitan dengan permasalahan yang dibahas (Umaiya \& Ibrahim, 2021). Pendekatan yuridisnormatif meneliti bahan-bahan kepustakaan atau data sekunder.

\section{HASIL DAN PEMBAHASAN}

\section{Tinjauan Yuridis Perlindungan Hukum Bagi Konsumen dalam Transaksi E-commerce}

Lahirnya internet dapat mendorong lahirnya paradigma baru dalam wahana perdagangan karena dengan adanya peluang dalam memilih media untuk melakukan kegiatan bertransaksi. Dengan lahirnya media internet dapat memberikan kemudahan kepada konsumen dan pelaku usaha dalam melakukan transaksi dan kegiatan transaksi e-commerce itu sendiri dapat mengacu pada konsep perikatan dalam KUHPerdata. Internet dewasa ini menjadi sangat penting, meskipun jika disimak secara konsep yang lebih jauh internet hanyalah suatu media atau alat untuk melakukan transaksi. Tetapi konsep perdagangan itu sendiri tetap memiliki hubungan hukum yang selama ini kita kenal. Dengan demikian, perdagangan melalui internet atau yang selama ini dikenal dengan transaksi e-commerce bukan merupakan hal yang baru.

Di Indonesia sendiri telah banyak jumlah pengguna internet yang memberi dampak pada berkembangnya transaksi jual-beli yang dilakukan secara online. Transaksi melalui sistem elektronik seperti inilah yang menarik perhatian masyarakat karena para pelaku usaha dan konsumen dapat bertransaksi tanpa harus saling bertatap muka dan cukup dengan berkomunikasi 


\section{Journal of Law, Administration, and Social Science}

melalui media elektronik. Hal ini dapat meningkatkan potensial pasar karena konsumen dapat melakukan transaksi dengan produsen atau distributor di seluruh penjuru dunia. Peningkatan perkembangan transaksi $e$-commerce yang pesat pastinya dapat menimbulkan dampak negatif bagi konsumen, yaitu kecenderungan pelaku usaha memposisikan konsumen pada posisi tawar yang lemah dan kebocoran data oleh peretas.

Beberapa faktor yang akan menimbulkan dampak negatif itu munculnya peningkatan pengaduan e-commerce di Yayasan Lembaga Konsumen Indonesia. Pada tahun 2015 yang awalnya terlapor 77 kasus, mengalami peningkatan pada tahun 2016, yaitu sebanyak 781 pengaduan melalui surat/datang langsung dan 10.038 pengaduan lewat telepon. Bahkan pada tahun 2017, data YLKI menyebutkan peringkat pertama pengaduan ke YLKI diduduki oleh e-commerce. Berdasarkan kasus-kasus pengaduan yang ada tentang transaksi online, maka diperlukan perlindungan hukum dan perlindungan konsumen.

Perlindungan hukum adalah perlindungan bagi subjek hukum atas pengakuan serta harkat dan martabat terhadap hak-hak asasi manusia berdasarkan ketentuan hukum dari yang berwenang. Perwujudan perlindungan untuk masyarakat dalam melindungi korban kejahatan dapat dilakukan dalam berbagai bentuk, contohnya melalui kompensasi, pemberian restitusi, bantuan hukum, dan bahkan pelayanan medis. Perlindungan hukum diberikan kepada subjek hukum dapat bersifat preventif maupun represif serta berbentuk lisan maupun tertulis. Konsep bahwa suatu ketertiban, keadilan, kemanfaatan, kepastian, dan kedamaian berasal dari hukum adalah salah satu gambaran dari fungsi perlindungan hukum (Fitriana, 2020).

Upaya-upaya yang diberikan sebagai jaminan adanya kepastian hukum untuk memberikan perlindungan kepada konsumen adalah arti dari perlindungan konsumen. Cakupan luas yang dimiliki perlindungan konsumen meliputi perlindungan terhadap barang dan jasa yang dimulai dari tahap kegiatan saat mendapatkan barang dan jasa sampai dampak yang muncul dari pemakaian barang dan/atau jasa tersebut. Cakupan perlindungan konsumen itu dapat dikualifikasikan menjadi dua aspek, yaitu perlindungan mengenai barang yang diserahkan kepada konsumen mungkin tidak sesuai dengan apa yang sudah disepakati, dan perlindungan terhadap syarat-syarat yang telah diberlakukan secara tidak adil kepada konsumen.

Agar hukum perlindungan konsumen dapat ditegakkan, perlu diberlakukan asas-asas yang memiliki fungsi sebagai landasan penetapan hukum. Rumusan peraturan mengenai asas dan prinsip yang berlaku dalam hukum perlindungan konsumen terdapat di peraturan perundang-undangan yang menyatakan bahwa: perlindungan konsumen berasaskan manfaat, keadilan, keseimbangan, keamanan, dan keselamatan konsumen serta partisipasi hukum.

Sifat perlindungan hukum dibagi menjadi dua, yaitu preventif dan represif. Perlindungan preventif adalah suatu bentuk perlindungan sebagai pencegahan sebelum terjadinya pelanggaran yang diberikan oleh pemerintah. Perlindungan yang bersifat preventif ini terdapat dalam peraturan perundang-undangan yang bermaksud untuk mencegah suatu pelanggaran dan memberikan rambu dan batasan dalam melakukan suatu kewajiban. Sedangkan, perlindungan hukum yang bersifat represif adalah suatu bentuk sanksi, contohnya hukuman tambahan, sanksi, dan penjara yang akan diberikan sebagai perlindungan akhir apabila telah terjadi sengketa atau telah dilakukannya suatu pelanggaran.

Undang-Undang Nomor 7 Tahun 2014 tentang Perdagangan (UU Perdagangan) dengan jelas mengatur tentang transaksi e-commerce dalam bagian tersendiri, yaitu dalam bab tentang Perdagangan Melalui Sistem Elektronik. UU Perdagangan ini merupakan kebijakan perdagangan dengan mengedepankan kepentingan nasional sebagai manifestasi dari harapan dan keinginan untuk memajukan sektor perdagangan. Hal ini tentunya sangat jelas dalam Pasal 2 huruf (a) 


\section{Journal of Law, Administration, and Social Science}

tersebut yang berisi "kebijakan perdagangan disusun berdasarkan asas kepentingan nasional". Contoh yang termasuk dari asas kepentingan nasional antara lain meliputi: melindungi konsumen, mendorong daya saing perdagangan, memperluas pasar tenaga kerja, melindungi produksi dalam negeri, mendorong pertumbuhan ekonomi, menjamin ketersediaan/kelancaran barang dan jasa, penguatan UMKM dan lain sebagainya. Lebih lanjut, UU Perdagangan mendelegasikan pengaturannya pada Peraturan Pemerintah.

Perlindungan hukum bagi konsumen dalam transaksi perdagangan elektronik lainnya terdapat dalam Pasal 28 ayat (1) UU ITE yaitu: "Setiap orang dengan sengaja dan tanpa hak menyebarkan berita bohong dan menyesatkan yang mengakibatkan kerugian konsumen dalam transaksi elektronik". Ketentuan sanksi pidana yang diterapkan atas pelanggaran yang dilakukan dalam Pasal 28 ayat (1) terdapat dalam Pasal 45a ayat (1) UU ITE yaitu: "Setiap orang yang dengan sengaja dan tanpa hak menyebarkan berita bohong dan menyesatkan yang mengakibatkan kerugian konsumen dalam transaksi elektronik sebagaimana dimaksud dalam Pasal 28 ayat (1) dipidana dengan pidana penjara paling lama 6 (enam) tahun dan/atau denda paling banyak Rp.1.000.000.000,00 (satu miliar rupiah)”.

Prinsip perlindungan hukum di Indonesia adalah prinsip mengenai pengakuan dan perlindungan terhadap harkat dan martabat manusia yang bersumber dari Pancasila. Dari peraturan yang sudah diteliti prinsip untuk perlindungan hukumnya yaitu dapat dilihat dari perlindungan hukum preventif dan perlindungan hukum represif. Perlindungan hukum preventif bertujuan untuk mencegah terjadinya sengketa sedangkan perlindungan hukum represif sebaliknya yaitu bertujuan untuk menyelesaikan sengketa. Sebagai suatu hubungan hukum, transaksi dagang melalui sistem elektronik memungkinkan terjadinya sengketa antara para pihak, baik yang terjadi karena wanprestasi maupun pelanggaran hukum. Dalam transaksi dagang melalui sistem elektronik, para pihak membuat perjanjian yang dibuat melalui sistem elektronik, sehingga transaksi dagang ini termasuk dalam ruang lingkup hukum perdata. Dengan demikian penyelesaian sengketa yang terjadi dalam transaksi dagang melalui sistem elektronik tunduk pada ketentuan hukum perdata, yang penyelesaiannya dapat dilakukan melalui pengadilan (litigasi) atau penyelesaian di luar pengadilan (non-litigasi).

\section{Urgensi KUHD dalam mengatasi risiko cybercrime yang muncul dalam transaksi e-commerce}

KUHD (Kitab Undang-undang Hukum Dagang) adalah kitab hukum yang mengatur masalah yang timbul karena tingkah laku manusia dalam perdagangan/perniagaan. KUHD lahir bersama KUHPerdata (Kitab Undang-undang Hukum Perdata Kedua kitab undang-undang tersebut lahir pada tahun 1847 dan diumumkan melalui staatsblad No. 23 pada 30 april 1847 serta berlaku pada waktu yang bersamaan yaitu 1 Mei 1848. Disusun pada saat pemerintahan Hindia Belanda membuat KUHD tidak diperbaharui dan tidak mengikuti perkembangan transaksi perdagangan. Contohnya yaitu kemunculan e-commerce, hukum yang mengatur e-commerce terdapat pada UU ITE dan bukan pada KUHD.

Kemajuan teknologi yang begitu pesat membawa perubahan yang signifikan bagi pola hidup manusia, contohnya yaitu penggunaan teknologi komunikasi internet. dengan adanya internet, kita dapat berkomunikasi serta melakukan transaksi tanpa ada batasan ruang dan waktu. sekarang ini, banyak perusahaan yang beralih dari metode konvensional menjadi elektronik didukung oleh internet seperti website. hasil dari peralihan ini yaitu e-commerce yaitu prose penjualan dan pembelian produk, jasa, dan informasi yang dilakukan secara elektronik dengan jaringan internet menggunakan handphone atau alat elektronik lainnya yang mendukung. Praktek ini disebut juga dengan belanja online. 
Faktor-faktor konsumen memilih berbelanja online antara lain dipengaruhi oleh iklan dan promo yang bertebaran di media sosial; kemampuan finansial konsumen; dan kemudahan dalam transaksi membuat konsumen terus menerus berbelanja online. Di sisi lain, terdapat pula faktorfaktor yang menyebabkan konsumen tidak berbelanja online, yaitu transaksi dan Perlindungan konsumen. penipuan yang terjadi dalam transaksi belanja online contohnya kartu kredit yang diakses oleh bukan pemilik, barang yang tidak sesuai, penjual tidak mengirim barang sampai ke tujuan, atau proses pengiriman barang lama; harga barang yang ditawarkan jauh lebih mahal dari toko konvensional; barang yang dijual sudah tidak memiliki garansi; dan tidak mengerti cara berbelanja online.

Hal yang menjadi alasan terbesar konsumen tidak berbelanja secara online tidak lain yaitu keamanan konsumen itu sendiri mulai dari penipuan transaksi, penipuan barang yang dibeli, dan lain-lain. Tindakan tersebut dikategorikan sebagai cybercrime atau kejahatan dunia maya. akan tetapi, apakah di Indonesia tindakan pencegahan maupun pemberantasan telah dilakukan? apakah ada hukum yang mengatur mengenai hal ini? sampai saat ini, UU ITE menjadi tameng hukum bagi para pelaku usaha dan pembeli secara online. Undang-Undang Nomor 11 tahun 2008 tentang Informasi dan Transaksi Elektronik sebagaimana telah diubah dengan Undang-Undang Nomor 19 Tahun 2016 (UU ITE) disahkan pada tanggal 21 April 2008 dan menjadi cyber law pertama di Indonesia. Pada 27 Oktober 2016 rapat paripurna Dewan Perwakilan Rakyat mengesahkan UU Nomor 19 Tahun 2016 tentang Perubahan Atas Undang-Undang Nomor 11 Tahun 2008. Pasal yang diubah adalah Pasal 27 ayat (1) dan (3), Pasal 28 ayat (2), dan Pasal 31 ayat (3). Manfaat UU ITE bagi transaksi e-commerce antara lain: (1) menjamin kepastian hukum transaksi elektronik seperti pengakuan informasi, dokumen, dokumen, dan tanda tangan elektronik dalam rangka hukum perikatan dan pembuktian; dan (2) melakukan klasifikasi tindakan-tindakan yang termasuk kualifikasi pelanggaran hukum terkait penyalahgunaan teknologi informasi disertai dengan sanksi pidananya.

Perjanjian yang dipakai dalam aktivitas e-commerce pada dasarnya sama dengan perjanjian yang dilakukan dalam transaksi konvensional, akan tetapi perjanjian yang dipakai dalam $e$ commerce merupakan perjanjian yang dibuat secara elektronik atau melalui sistem elektronik (Pasal 1 Angka 17 UU ITE).

Beberapa pasal ada yang menyinggung mengenai pelanggaran dalam bertransaksi antara lain menurut pasal 246 KUHD Asuransi dan pertanggungjawaban dengan memperoleh premi, untuk memberikan ganti rugi karena suatu kehilangan, kerusakan, atau tidak mendapat keuntungan yang diharapkan yang mungkin akan dapat diderita karena suatu peristiwa tidak pasti.

\section{Bagaimana penyelesaian sengketa antara konsumen dengan pelaku usaha dalam transaksi dagang melalui transaksi e-commerce?}

Hukum perlindungan konsumen dengan tujuan memberikan perlindungan oleh hukum kepada konsumen sekaligus tercapainya tujuan hukum yaitu memberi perlindungan kepada masyarakat, terdapat UU yang mengatur mengenai hal ini. Di Indonesia, pendapat pasal yang mengatur perlindungan terhadap konsumen yaitu Pasal 1 UU Perlindungan konsumen. Akan tetapi, Undang-undang tersebut belum mengatur transaksi elektronik yang saat ini menjadi fokus utama transaksi perdagangan. hal ini menyebabkan perlindungan terhadap konsumen kembali menjadi tanda tanya (Karinda et al., 2020).

Terdapat beberapa kasus yang membuat konsumen sulit untuk melakukan perlawanan jika terjadi sengketa. Contohnya ketika konsumen meninggal, yang mengambil alih yaitu ahli waris dan mau melakukan perlawanan ini akan ditangkis oleh pelaku usaha dengan anggapan mereka bukan konsumen akhir. Oleh karena itu, perlu diadakan perbaikan Undang-undang Perlindungan 
Journal of Law, Administration, and Social Science

Volume 2 No. 1, 2022

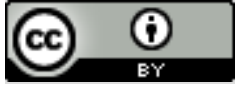

Konsumen. Menanggapi hal ini, pemerintah mengeluarkan Peraturan Pemerintah Nomor 59 Tahun 2001 tentang Perlindungan Konsumen.

Selama proses transaksi, konsumen dituntut untuk lebih teliti sebagai bentuk pencegahan kejahatan selama transaksi berlangsung (Prasetyo et al., 2021). Pada masa saat ini, transaksi online kerap kali memakan banyak korban penipuan transaksi contohnya selisih harga yang berbeda antara yang tertera di situs dan jumlah yang dibayarkan tetapi konsumen lebih memilih diam saat kejadian seperti itu terjadi. Sesuai dengan peraturan Permendag No. 35/M-Dag/Per/7/2013 Jika terjadi hal seperti contoh, maka harga yang dikenakan yaitu harga terendah.

Ekspektasi konsumen dibagi menjadi tepat harga, tepat mutu, dan tepat kuantitas. Jika ingin ekspektasinya terpenuhi, konsumen bisa memperbanyak literasi antara konsumen dan pelaku usaha. Jenis-jenisnya antara lain: Pertama, literasi pra transaksi. Para pelaku usaha sebaiknya memberikan informasi yang benar kepada konsumen sehingga konsumen mendapat informasi yang sama. Hal ini akan memuaskan konsumen karena ekspektasinya kepada barang terpenuhi. Literasi pra transaksi ini telah tertuang di dalam Undang-undang Perlindungan Konsumen. Pada pasal 4 e, $\mathrm{b}$, f dan pasal 5 huruf a mengatur hak konsumen serta pasal 7 a mengatur kewajiban pelaku usaha. Kedua, literasi proses transaksi. Pelaku usaha harus memperlakukan konsumen atau melayani konsumen secara benar dan jujur serta tidak diskriminatif, dalam hal menjual barang atau jasa pelaku usaha harus menjamin mutu berdasarkan ketentuan dasar mutu barang atau jasa. Konsumen memiliki hak atas kenyamanan, keamanan dan keselamatan dalam mengkonsumsi barang atau jasa tersebut. Terkait dengan norma literasi proses transaksi diatur dalam UU Perlindungan Konsumen. Hak konsumen diatur dalam pasal 4 huruf a, c, dan g dan f serta pasal 5 huruf b dan c. Sedangkan kewajiban pelaku usaha diatur dalam pasal $7 \mathrm{c}$ dan d. Ketiga, literasi pasca transaksi atau purna jual. Jika terjadi kesalahan selama transaksi, maka pelaku usaha wajib memberikan kompensasi atau biasa kita sebut ganti rugi atas kerugian yang ditanggung oleh pembeli. Terkait sengketa seperti ini, konsumen mendapat perlindungan selama menyelesaikan sengketa. Hak konsumen diatur pada pasal $4 \mathrm{c}$, h, dan i dan pasal $5 \mathrm{~d}$ serta kewajiban pelaku usaha diatur dalam pasal $7 \mathrm{f}$ dan g.

Undang-undang Perlindungan Konsumen dan Undang-undang ITE dijadikan landasan dalam transaksi elektronik serta menyelesaikan sengketa yang terjadi. Peraturan Pemerintah Nomor 71 Tahun 2019 tentang penyelenggaraan elektronik Pasal 22 ayat (1) mengatur penyelenggaraan wajib memberikan rekam jejak elektronik. Rekam jejak diperlukan dalam rangka penegakan hukum, verifikasi, penyelesaian sengketa, pemeriksaan, pengujian, dan lain-lain. Jika hal ini tidak dilakukan, maka akan kena sanksi pidana maksimal lima tahun penjara.

Hal yang penting untuk dilakukan pengecekan terlebih dahulu klausula baku dari pelaku usaha. Terdapat klausula baku yang merugikan konsumen dan konsumen dapat melaporkannya pada BPSK (Badan Penyelesaian Sengketa Konsumen). hal ini juga dapat dilakukan pada masa pra transaksi jika konsumen mendapat kejanggalan juga saat konsumen sudah menandatangani perjanjian dan dianggap sah BPSK akan tetap menindaklanjutinya. Oleh karena itu, agar tindakan seperti ini tidak terjadi, konsumen harus memahami smart contract karena penyelesaian sengketa dilakukan secara online (Firdaus, 2020).

Pengadilan juga mengambil andil dalam sengketa antara konsumen dan pelaku usaha karena pengajuan dari BPSK. Sebesar 80\% putusan BPSK dibatalkan oleh pengadilan. Hali ini bisa terjadi karena disebabkan tidak adanya upaya hukum dalam jangka waktu 14 hari putusan. Akan tetapi, bisa saja terjadi karena pelaku usaha melakukan perlawanan di pengadilan sedangkan konsumen lemah karena tidak memiliki pengacara. BPSK harus memperkuat 


\section{Journal of Law, Administration, and Social Science}

Volume 2 No. 1, 2022

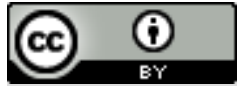

kedudukannya untuk melakukan putusan agar kuat di pengadilan dan pengawasan dan penerapan perlindungan terjalankan.

Pengertian awal dari sengketa konsumen adalah sengketa yang terjadi antara pelaku usaha dan konsumen karena transaksi barang/jasa. Dalam sidang BPSK, konsumen diberikan kesempatan untuk memilih jenis penyelesaian yaitu media, konsiliasi, atau arbitrase. Jika pihak lain tidak memiliki pilihan atas jenis penyelesaian tersebut, maka BPSK akan menjalankan tugasnya dengan memanggil pihak UPT (Unit Pelaksanaan Teknis) untuk melakukan mediasi awal, apabila mediasi gagal maka diadakan arbitrase, dan dilaksanakan sidang tertutup.

BPSK (Badan Penyelesaian Sengketa Konsumen) memiliki tiga majelis hakim, antara lain: unsur pemerintahan, unsur pelaku usaha, dan unsur masyarakat.

Terdapat dua alur persidangan BPSK (Badan Penyelesaian Sengketa Konsumen) yaitu alur konvensional dan alur elektronik. keduanya sama saja dilakukan oleh konsumen akhir atau ahli waris. dilakukan gelar perkara untuk memastikan kelayakan sengketa tersebut untuk diajukan ke pengadilan dan jangka waktunya tidak melebihi 21 hari kerja. jika lewat 21 hari kerja, tidak diajukan ke pengadilan karena tidak di undang-undang Perlindungan Konsumen.

BPKN (Badan Perlindungan Konsumen Nasional) menjadi jalan terakhir jika ada sengketa yang tidak masuk ke pengadilan. Putusan dari BPSK (Badan Penyelesaian Sengketa Konsumen) bisa saja tidak diterima oleh pengadilan karena dianggap tidak berwenang dalam mengadili perkara. hali ini karena sengketa tersebut masuk ke dalam perkara keperdataan. dapat disimpulkan bahwa kewenangan BPSK tidak menitikberatkan pada sengketa keperdataan tetapi terkait perilaku konsumen.

\section{PENUTUP \\ Simpulan}

Kegiatan bertransaksi kini lebih mudah karena lahirnya internet dalam wahana perdagangan yang dapat memberikan kemudahan kepada konsumen dan pelaku usaha. Meskipun menawarkan banyak kemudahan, tentu tetap ada kemungkinan kejahatan, contohnya kejahatan siber. Maka dari itu, dibutuhkan perlindungan hukum, misalnya melalui kompensasi dan bantuan hukum. Tujuannya agar masyarakat merasakan keadilan dan kepastian. Salah satu perlindungan konsumen dalam transaksi e-commerce terdapat dalam Pasal 28 ayat (1) UU ITE yang berbunyi "Setiap orang dengan sengaja dan tanpa hak menyebarkan berita bohong dan menyesatkan dan mengakibatkan kerugian konsumen dalam Transaksi Elektronik."

E-commerce hadir di Indonesia merupakan suatu yang mudah ditebak, globalisasi membawa arus yang cepat. Perdagangan cara ini digunakan masyarakat negara maju seperti Amerika Serikat, Jepang, Inggris, kemudian merambat ke seluruh dunia. Hal ini berkembang pesat di Indonesia sejak munculnya e-commerce karya anak negeri seperti Tokopedia, Bukalapak, Blibli, dan lain-lain. E-commerce hadir di Indonesia pada tahun 2010-201, lebih dari 10 tahun, tetapi belum tertera pada KUHD hingga saat ini.

KUHD tidak memiliki peraturan mengenai e-commerce secara umum, maupun cybercrime yang terjadi pada pelaku usaha maupun pembeli e-commerce. hal ini cukup disayangkan mengingat pada era saat ini, perdagangan secara konvensional semakin tergerus zaman, masyarakat dari segala usia beralih menggunakan perdagangan online karena dianggap lebih mudah dan efisien. Peraturan mengenai sengketa antara konsumen dan pelaku usaha tertuang dalam pasal 1 UU Perlindungan Konsumen serta BPSK (Badan Penyelesaian Sengketa Konsumen) turut ambil andil dalam penyelesaian sengketa yang jika memenuhi syarat akan diusut ke pengadilan. 
Journal of Law, Administration, and Social Science

Volume 2 No. 1, 2022

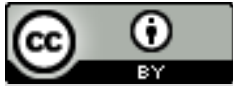

Saran

Kemajuan teknologi dalam bidang perdagangan/perniagaan tidak dapat dibendung. Hal ini meningkat secara instan semenjak awal masa pandemi karena tuntutan global yang memaksa para pelaku usaha bertransformasi dengan cepat agar tidak tergerus pasar. Tidak adanya ketentuan khusus mengenai perdagangan elektronik melalui e-commerce atau belanja online menjadi cermin belum siapnya hukum indonesia mengikuti perkembangan zaman. Saat ini, sengketa atau permasalahan yang terjadi masih bisa diatasi dengan undang-undang yang ada namun untuk ke depannya belum dapat dipastikan bentuk dan kompleksitasnya. Diharapkan aturan mengenai perdagangan elektronik ini secepatnya disusun dan diberlakukan di Indonesia. Untuk pengembangan riset, peneliti selanjutnya dapat mengelaborasi model KUHD yang tepat untuk mencegah dan menangani risiko kejahatan siber pada transaksi -commerce.

\section{DAFTAR PUSTAKA}

Budianto, A. (2013). Pembaharuan Kitab Hukum Dagang Indonesia: Antara Kodifikasi , Kompilasi dan Konsolidasi. Asy-Syir'ah Jurnal Ilmu Syari'ah Dan Hukum, 47(2), 703-725.

Bunga, D. (2019). Politik hukum pidana terhadap penanggulangan. Jurnal Legislasi Indonesia, 16 (1), 1-15. https://e-jurnal.peraturan.go.id/index.php/jli/article/view/456

Dani, S., \& Marlinah. (2019). Perkembangan Hukum Perusahaan di Indonesia. Jurnal Legitima, $19(1), 34-52$.

Eshafia, S. A. (2022). Perlindungan Hukum Pemagang yang Tidak Diikutsertakan BPJS oleh Perusahaan. Jurist-Diction, 5(1), 379. https://doi.org/10.20473/jd.v5i1.32730

Fathur, M. (2020). Tanggung Jawab Tokopedia Terhadap Kebocoran Data. National Conference on Law Studies (NCOLS), 2(1), 43-60.

Firdaus, D. H. (2020). Aplikasi Smart Contract dalam E-Commerce Prespektif Hukum Perjanjian Syariah. Jurnal Qolamuna, 6(1), 37-54.

Fitriana, W. (2020). Respon Hukum Indonesia Terhadap Transaksi Elektronik (E-Commerce). http://eprints.ums.ac.id/id/eprint/85077

Fitriono, R. A. (2011). Kebijakan Formulasi Hukum Pidana Dalam Melindungi Transaksi E Commerce Di Indonesia. Law Reform, 7(1), 76-108. https://doi.org/10.14710/lr.v7i1.12479

Frastian, N. (2017). Implementasi Protokol S/MIME pada Layanan E-mail Peningkatan Jaminan Keamanan Secara Online pada Kantor PT Tammar Frasti. STRING (Satuan Tulisan Riset Dan Inovasi Teknologi), 2(2), 177. https://doi.org/10.30998/string.v2i2.2104

Harahap, D. A. (2018). Perilaku Belanja Online Di Indonesia: Studi Kasus. JRMSI - Jurnal Riset Manajemen Sains Indonesia, 9(2), 193-213. https://doi.org/10.21009/jrmsi.009.2.02

Irmawati, D. (2011). Pemanfaatan E-Commerce dalam Dunia Bisnis. Jurnal Ilmiah Orasi Bisnis, $6,161-171$.

Karinda, R. A., Wahongan, anna S., \& Umboh, K. Y. (2020). Perlindungan Hukum terhadap Konsumen dalam bisnis Pembiayaan Menurut Undang-Undang Nomor 8 Tahun 1999. Lex Privatum, VIII(4), 47-57.

Kathleen, G. A., Hukum, F., Pembangunan, U., \& Veteran, N. (2021). Perlindungan Hukum terhadap Tertanggung atas Penolakan Klaim Asuransi Jiwa dengan Alasan Klaim dalam Masa Tunggu. JUSTITIA: Jurnal Ilmu Hukum Dan Humaniora, 8(5), 919-930.

Komalawati, D., M.R., M. D., \& Kartika, R. D. (2021). Kejutan Puluhan Miliar Tokopedia Di Tengah Kasus Kebocoran Data. Jurnal Syntax Admiration, 2(1), 49-56.

Lukito, I. (2017). Tantangan Hukum dan Peran Pemerintah dalam Pembangunan E-Commerce (Legal Challenges and Government'S Role in E-Commerce Development). Jurnal Ilmiah 
Kebijakan Hukum, 11(3), 349-367.

Makarim, E. (2014). Kerangka Kebijakan Dan Reformasi Hukum Untuk Kelancaran Perdagangan Secara Elektronik (E-Commerce) Di Indonesia. Jurnal Hukum \& Pembangunan, 44(3), 314. https://doi.org/10.21143/jhp.vol44.no3.25

Murifal, B. (2018). Peran Teknologi Finansial Sistem P21 Sebagai Alternatif Sumber Pendanaan UMKM. Perspektif, XVI(2), 202-208.

Pariadi, D. (2018). Pengawasan E Commerce Dalam Undang-Undang Perdagangan Dan UndangUndang Perlindungan Konsumen. Jurnal Hukum \& Pembangunan, 48(3), 652. https://doi.org/10.21143/jhp.vol48.no3.1750

Prasetyo, K. Y., Damayanti, F., Basith, A., Utami, M. wiji, Abdillah, R. F., \& Khairunnisa. (2021). Pengaruh E-. Journal of Education and Technology, 1(2), 81-86.

Ramli, T. S., Ramli, A. M., Permata, R. R., Ramadayanti, E., \& Fauzi, R. (2020). Aspek Hukum Platform e-Commerec dalam Era Transformasi Digital. Jurnal Studi Komunikasi Dan Media, 24(2), 119. https://doi.org/10.31445/jskm.2020.3295

Rongiyati, S. (2019). Perlindungan konsumen dalam transaksi dagang melalui sistem elektronik. Pusat penelitian badan keahlian DPR RI. Negara Hukum, 10(1), 1-25. https://jurnal.dpr.go.id/index.php/hukum/article/download/1223/pdf

Sadino, \& Dewi, L. K. (2016). Internet Crime dalam Perdagangan Elektronik. Jurnal Magister Ilmu Hukum, 1(2), 9-17.

Sewang, A. (2017). Keberterimaan Google Classroom sebagai Alternatif Peningkatan Mutu di IAI DDI Polewali Mandar. Jurnal Pendidikan Islam Pendekatan Interdisipliner, 1(1), 35-46.

Subekti, S. (2017). Analisis Yuridis Tentang Hukum Asuransi Dalam Transaksi Electronic Commerce Melalui Perspektif Kitab Undang-Undang Hukum Dagang. Jurnal Ilmiah Dunia Hukum, 1(1), 19. https://doi.org/10.35973/jidh.v1i1.604

Sumadi, H. (2016). Kendala Dalam Menanggulangi Tindak Pidana Penipuan Transaksi Elektronik Di Indonesia. Jurnal Wawasan Yuridika, 33(2), 175. https://doi.org/10.25072/jwy.v33i2.102

Umaiya, S. I., \& Ibrahim, M. (2021). Tinjauan Normatif dan Yuridis terhadap Pelaksanaan Wakaf Uang secara Online pada Lembaga Wakaf. Az-Zarqa', 13(2), 202-222.

Utami, N., Silalahi, P. R., \& Tambunan, K. (2022). Pengaruh Brand Ambasador terhadap Keputusan Pembelian pada e-Commerce Tokopedia (Studi Kasus Remaja Kota Medan). Jurnal Ilmu Komputer, Ekonomi Dan Manajemen (JIKEM), 2(1), 41-46. 